\title{
Effect of composition of ruminally-infused short-chain fatty acids on net fluxes of nutrients across portal-drained viscera in underfed ewes
}

\author{
Pierre Nozière $^{1 *}$, Cécile Martin ${ }^{1}$, Didier Rémond ${ }^{1}$, Niels B. Kristensen ${ }^{2}$, Richard Bernard $^{1}$ \\ and Michel Doreau ${ }^{1}$ \\ ${ }^{1}$ Unité de Recherches sur les Herbivores, INRA Theix, 63122 Saint-Genès-Champanelle, France \\ ${ }^{2}$ Department of Animal Nutrition and Physiology, Danish Institute of Agricultural Sciences, Box 50, DK-8830 Tjele, Denmark
}

(Received 12 April 1999 - Revised 21 July 1999 - Accepted 27 August 1999)

\begin{abstract}
Four ewes, each fitted with a rumen cannula and with catheters in the mesenteric artery and portal and mesenteric veins, received continuous intrarumen infusions of water or of short-chain fatty acids (SCFA). SCFA infusions were isoenergetic $(83 \mathrm{~kJ} / \mathrm{h})$ and provided rumen molar proportions (acetate : propionate : butyrate) of $70: 20: 10,50: 40: 10$ or $50: 20: 30$. The rumen SCFA production rate with the basal diet was $90 \cdot 0,23.1$ and $8.8 \mathrm{mmol} / \mathrm{h}$ for acetate, propionate and butyrate respectively. Portal net fluxes indicated that 74, 67 and $22-30 \%$ of infused acetate, propionate and butyrate respectively, reached the portal vein. Portal net release of $\beta$-hydroxybutyrate increased with SCFA infusions, irrespective of the amount of butyrate infused. Portal net release of lactate decreased with high-butyrate infusion. Portal net uptake of glucose increased with the SCFA infusions. In ewes infused with water, a portal net uptake of total amino acids (AA) was observed. SCFA infusions decreased the uptake of nonessential AA (glutamate, glycine, but not glutamine) and increased the net release of tyrosine and essential AA (isoleucine, leucine). Portal net fluxes of AA were similar with both high-acetate and high-propionate infusions. Lower net uptake of glutamine and net release of most essential AA and some nonessential AA were observed with the high-butyrate infusion. Energetic summation of portal net release was not significantly different between the three SCFA infusions, although it tended to be lower with highbutyrate infusion. This may be related to the higher trophic effect of butyrate on the digestive mucosa.
\end{abstract}

Sheep: Short-chain fatty acids: Portal fluxes: Amino acids

The high oxidative activity of portal-drained viscera (PDV) contributes $15-25 \%$ of whole-animal energy maintenance expenditure in ruminants (for review see Huntington, 1990). Changes in intake result in variations in weight of PDV and thus contribute to changes in the maintenance requirements of the animal according to its feeding level (for review see Ortigues \& Doreau, 1995), and to the amount of energy metabolizable by peripheral producing tissues such as muscles or mammary glands. PDV metabolism appears to be closely related to the metabolizable energy (ME) intake but dietary factors involved in this relationship are not well known (for review see Goetsch, 1998). Increases in the filling of the digestive tract and in the amount of nutrients produced may both be considered to be responsible for the increase in PDV metabolism induced by the increase in intake. Moreover, the effects of the composition of rumen short-chain fatty acids (SCFA), which account for the main energy source absorbed in the portal vein and which vary considerably according to the nature of the diet, are still not well known due to the lack of direct comparisons. Intrarumen infusions of SCFA allow an increase in ME intake without change in the filling of the digestive tract. The aim of this present study was to determine whether the composition of ruminally-infused SCFA changes the amount and the composition of energy reaching the portal vein. Three different infusions were used, allowing rumen molar proportions of SCFA close to those obtained with highforage, high-cereal or high-soluble-carbohydrate diets.

\section{Materials and methods \\ Animals, feeding and infusions}

Four adult (2.5 years), non-pregnant and non-lactating Lacaune ewes of 56.4 (SD 1.5) kg body weight were used. They were surgically fitted with a rumen cannula and with

\footnotetext{
Abbreviations: AA, amino acid; ME, metabolizable energy; NEFA, non-esterified fatty acid; PAH, p-aminohippuric acid; PDV, portal-drained viscera; SCFA, short-chain fatty acid.

* Corresponding author: Dr Pierre Nozière, fax +33 4736245 19, email noziere@ clermont.inra.fr
} 
long-term catheters in the portal vein, a mesenteric artery and a mesenteric vein as described by Ortigues et al. (1994). The animals were housed in an air-conditioned room in individual boxes $\left(1.5 \mathrm{~m}^{2}\right)$. They were able to ingest the experimental diet $3 \mathrm{~d}$ after surgery. This diet consisted of $482 \mathrm{~g} \mathrm{DM} / \mathrm{d}$ of a first-cut of natural grassland hay, with ME and crude protein contents of $8.14 \mathrm{MJ}$ and $89.5 \mathrm{~g} / \mathrm{kg} \mathrm{DM}$ respectively. This diet provided 53 and $54 \%$ of their net energy and $\mathrm{N}$ requirements respectively, taken according to the French feeding systems (Institut National de la Recherche Agronomique, 1989). They also received $10 \mathrm{~g}$ mineral supplement/d (Ca 150, P 100 and $\mathrm{Mg} 20 \mathrm{~g} / \mathrm{kg}$ ) containing vitamins and trace elements and had free access to water and block salt. Hay was offered every $3 \mathrm{~h}$ in eight equal meals per $\mathrm{d}$ by an automatic feeder throughout all the experiment.

After $10 \mathrm{~d}$ to recover from surgery, each ewe received four intrarumen infusions (Table 1) in a $4 \times 4$ Latin square experimental design. Each infusion was maintained for 1 week with a flow rate of $3 \mathrm{l} / \mathrm{d}$. The control infusion (C) consisted only of water. The other three infusions were prepared in a mineral buffer $\left(36.5 \mathrm{~g} \mathrm{NaHCO}_{3} / 1,19.0 \mathrm{~g}\right.$ $\mathrm{KHCO}_{3} / \mathrm{l}$ and $\left.3.5 \mathrm{~g} \mathrm{NaCl} / \mathrm{l}\right)$. They were isoenergetic $(0.64 \mathrm{~kJ} \mathrm{ME} / \mathrm{ml})$ and their molar proportions of SCFA (acetate : propionate: butyrate) were 70:20:10 (infusion A), $13: 77: 10$ (infusion $P$ ) and $0: 20: 80$ (infusion $B$ ). The infusions were chosen in order that the amount of SCFA produced by the rumen fermentation of the hay plus the amount of SCFA infused should induce molar proportions of SCFA in the rumen of approximately $70: 20: 10$ for infusion A (as with high-fibre diets), 50:40:10 for infusion $\mathrm{P}$ (as with high-cereal diets), and 50:20:30 for infusion $\mathrm{P}$ (as with high-soluble-carbohydrate diets).

\section{Measurements}

Digestibility, short-chain fatty acid production, rumen sampling and measurements. Digestibilities of DM, organic matter, neutral detergent fibre and acid detergent fibre were measured on five consecutive days by total faeces collection, starting $2 \mathrm{~d}$ after the beginning of the infusion (Laboratoire Cilal, St-Genès-Champanelle, France). For each treatment, rumen and blood sampling were carried out on the same day. To calculate the volume and the turnover rate of the rumen liquid phase, a pulse dose of CrEDTA
(140 $\mathrm{mg} \mathrm{Cr}$ in $50 \mathrm{ml}$ water) was infused into the rumen at 08.55 hours. Rumen contents were sampled via the rumen cannula using a tube placed in the ventral sac at 08.50 , $11.00,13.00,14.50,17.00$ and 23.00 hours the same day, 08.00 and 13.00 hours the following day. $\mathrm{Cr}$ in rumen contents was then measured by atomic absorption spectrophotometry (Binnerts et al. 1968). The $\mathrm{pH}$ was immediately measured on the samples taken at $08.50,11.00,13.00$ and 14.50 hours, using a combination electrode. The osmolality was determined on two pooled samples (08.50 and 14.50 hours, 11.00 and 13.00 hours, i.e. before and $1-2 \mathrm{~h}$ after a meal respectively). SCFA concentration and composition were determined on the same pooled samples preserved with $0 \cdot 1$ volume of orthophosphoric acid $(1: 19 \mathrm{v} / \mathrm{v})$ by GC using 4-methylvaleric acid as an internal standard (Jouany, 1982).

The SCFA production rate from hay degradation was measured for the control diet (C) on the same four ewes 1 week after the end of the Latin square. Because exchange of propionic acid C with other SCFA is quantitatively insignificant (Peters et al. 1990), $\left[{ }^{13}\right.$ C]propionate was chosen as the reference to predict in vivo production rate of all SCFA. After sampling $30 \mathrm{ml}$ rumen liquid (blank for analyses), a solution of $\left[1{ }^{13} \mathrm{C}\right]$ propionate $(34.6 \mathrm{mg} / \mathrm{h}$, i.e. $0.460 \mathrm{mmol}\left[1-{ }^{13} \mathrm{C}\right]$ propionate $/ \mathrm{h}, 99.9 \%$ enriched; Leman, St Quentin en Yvelines, France) was continuously infused $(130 \mathrm{ml} / \mathrm{h})$ into the rumen for $24 \mathrm{~h}$. After the beginning of the infusion $(16 \mathrm{~h})$, six samples of rumen contents $(30 \mathrm{ml}$ each) were taken every $1.5 \mathrm{~h}$. The ${ }^{13} \mathrm{C}$-enrichment of rumen propionate was determined on 2-chloroethyl esters of propionate by $\mathrm{GC}$-isotope ratio mass spectrometry (Tetens et al. 1995; Kristensen et al. 1999).

Blood sampling and measurements. Animals were studied for $1 \mathrm{~d}$ per period, 5 or $6 \mathrm{~d}$ following the beginning of the infusion. The morning of the sampling day, $p$-aminohippuric acid (PAH) dissolved $(100 \mathrm{~g} / \mathrm{l})$ in a physiological sterile saline solution ( $\mathrm{pH} 7.4$ ) was infused continuously via the mesenteric vein $(7.2 \mathrm{ml} / \mathrm{h})$ after a prime injection $(2.25 \mathrm{ml})$ at 08.30 hours. Blood sampling started at 09.15 hours, i.e. $15 \mathrm{~min}$ after a meal, and was repeated at intervals of 30 min over two feeding cycles. At each sampling time, blood samples were taken from mesenteric artery and portal vein $(7 \mathrm{ml}$ each) using syringes containing EDTA-K as anticoagulant. Immediately after sampling, blood syringes were gently inverted to mix avoiding haemolysis, and

Table 1. Intrarumen infusion rate of short-chain fatty acids (SCFA) (mmol/h), metabolizable energy (ME) $(\mathrm{kJ} / \mathrm{h})$ and water $(\mathrm{ml} / \mathrm{h})$ (Means with standard errors for four ewes)

\begin{tabular}{|c|c|c|c|c|c|c|c|}
\hline & \multirow[b]{2}{*}{ C } & \multicolumn{3}{|c|}{ SCFA infusion† } & \multirow[b]{2}{*}{ SE } & \multicolumn{2}{|c|}{ Contrasts } \\
\hline & & $A$ & $\mathrm{P}$ & B & & Level & Composition \\
\hline Acetate & $0.00^{a}$ & $43.03^{b}$ & $7.25^{c}$ & $0.00^{a}$ & 1.60 & $* \star \star$ & $\star \star \star *$ \\
\hline Propionate & $0.00^{\mathrm{a}}$ & $13 \cdot 78^{\mathrm{b}}$ & $44.51^{\mathrm{C}}$ & $8.93^{d}$ & 1.73 & $* * *$ & $* * *$ \\
\hline Butyrate & $0.00^{a}$ & $6.58^{\mathrm{b}}$ & $5.74^{\mathrm{b}}$ & $34 \cdot 18^{c}$ & 0.88 & $* * *$ & $* * *$ \\
\hline $\mathrm{ME}$ & $0.00^{a}$ & $73 \cdot 16^{b}$ & $87 \cdot 18^{b}$ & $88.53^{b}$ & 4.83 & $* * *$ & * \\
\hline Water & $114 \cdot 2^{\mathrm{a}}$ & $119 \cdot 4^{\mathrm{a}}$ & $133.1^{\mathrm{a}}$ & $137 \cdot 6^{a}$ & 7.6 & NS & NS \\
\hline
\end{tabular}

\footnotetext{
a,b,c,d Mean values within a row with unlike superscript letters were significantly different $(P<0 \cdot 10)$.

${ }^{\star \star \star} P<0.001 ;{ }^{*} P<0.10$; NS, not significant $(P>0.10)$.
}

†For details of infusions see p. 522. 
packed cell volume was determined in triplicate by centrifuging blood in capillary tubes. $\mathrm{NH}_{3}$, urea and $\mathrm{PAH}$ were determined in blood by the phenol-hypochlorite (Weatherburn, 1967), the diacetylmonoxime (Marsh et al. 1965) and the $N$ - $\alpha$-naphtyl ethylene diamine dichlorhydrate (Bratton \& Marshall, 1939) automated methods respectively, using a continuous autoanalyser (Alliance, Méry-sur-Oise, France) as described by Rémond et al. (1993) and Isserty et al. (1998). Enzymic determinations of $\beta$-hydroxybutyrate (Barnouin et al. 1986) in blood deproteinized by 2 volumes of $\mathrm{HClO}_{4}(0.6 \mathrm{~N})$, of glucose (Merckotest kit, Merck, Nogent-sur-Marne, France), lactate (BioMérieux SA kit, Marcy-l'Etoile, France) and non-esterified fatty acids (NEFA; Wako kit, Biolyon, Lyon, France) in plasma were performed using a multianalyser (Elan, Merck-Clevenot, Nogent-sur-Marne, France). After an extraction derived from Brighenti (1997) by deproteinization with 0.26 volumes of metaphosphoric acid (400 g/l) (Prolabo, Fontenay-sousBois, France), SCFA were analysed in blood by GC with 2-ethylbutyric acid as internal standard. The chromatograph was a GC 8000 with a AS 800 autosampler (Fisons Instruments, Milan, Italy), a split/splitless injector in the splitless mode operated at $170^{\circ}$ and an FID detector operated at $240^{\circ}$. The column was $30 \mathrm{~m} \times 0.53 \mathrm{~mm} \times 1 \mu \mathrm{m}$ (HP-FFAP, Hewlett Packard, Waldbroom, Germany), programmed to increase up to $140^{\circ}$ at a rate of $25^{\circ} / \mathrm{min}$ after $1 \mathrm{~min}$ at $85^{\circ}$. He gas was used as a carrier. After deproteinization with $0 \cdot 1$ volume of sulfosalicylic acid $(400 \mathrm{~g} / \mathrm{l})$, deproteinized blood was conserved at $-80^{\circ}$ pending analysis of amino acids (AA) by ionexchange chromatography using an autoanalyser (Beckman Instruments, Palo Alto, CA, USA) with D-glucosaminic acid as internal standard. Since two molecules of cysteine are rapidly oxidized into one molecule of cystine, cystine concentration was determined and multiplied by two to give cysteine concentration.

\section{Calculations and statistical analyses}

The volume and the turnover rate of the rumen liquid phase was calculated from the exponential decrease of $\mathrm{Cr}$ concentrations with time. After semi-logarithmic linearization, the slope represented the turnover rate (per h), and the volume of liquid phase in the rumen was calculated as the amount of $\mathrm{Cr}$ infused/exp ${ }^{\text {(intercept at } t=0)}$.

Production rate of propionate $(\mathrm{mmol} / \mathrm{h})$ was calculated according to the following equation:

(AF infusate $-\mathrm{AF}$ background $) \times$ infusion rate/((AF rumen - AF background) $\times 3$ ),

where $\mathrm{AF}$ is the atomic fraction of ${ }^{13} \mathrm{C}={ }^{13} \mathrm{C} /\left({ }^{12} \mathrm{C}+{ }^{13} \mathrm{C}\right)$ and infusion rate is expressed in $\mathrm{mmol} / \mathrm{h}$. Production rates of acetate and butyrate were respectively obtained by multiplying the propionate production rate by the concentration ratios acetate : propionate and butyrate : propionate.

Blood (or plasma) flow $(\mathrm{F}, 1 / \mathrm{h})$ through PDV was calculated as described by Katz \& Bergman (1969):

$$
\mathrm{F}=\mathrm{I} /\left(\mathrm{PAH}_{\mathrm{pv}}-\mathrm{PAH}_{\mathrm{a}}\right),
$$

where $\mathrm{I}$ is $\mathrm{PAH}$ infusion rate $(\mathrm{g} / \mathrm{h})$ and $\mathrm{PAH}_{\mathrm{pv}}, \mathrm{PAH}_{\mathrm{a}}$ are the concentrations of PAH $(\mathrm{g} / \mathrm{l})$ in the portal vein and arterial blood (or plasma) respectively. As all PAH is recovered in the plasma fraction, concentrations of PAH in plasma $\left(\mathrm{PAH}_{\mathrm{p}}\right)$ were derived from blood values $\left(\mathrm{PAH}_{\mathrm{b}}\right)$ and packed cell volume (PCV (\%)), as described by Nozière et al. (1998):

$$
\mathrm{PAH}_{\mathrm{p}}=\left(100 \times \mathrm{PAH}_{\mathrm{b}}\right) /(100-\mathrm{PCV}) .
$$

Net flux of metabolites (NF, $\mathrm{mmol} / \mathrm{h}$ ) through PDV were calculated as described by Katz \& Bergman (1969):

$$
\mathrm{NF}=\mathrm{F}\left(\mathrm{M}_{\mathrm{pv}}-\mathrm{M}_{\mathrm{a}}\right),
$$

where $\mathrm{F}$ is blood (or plasma) flow, $\mathrm{M}_{\mathrm{pv}}$ and $\mathrm{M}_{\mathrm{a}}$ are concentrations of metabolites (mM) in the portal vein and arterial blood (or plasma) respectively. Positive net fluxes represented net release in the portal vein, whereas negative net fluxes represented net uptake by PDV.

Summations of net portal energy fluxes were based on heats of combustion of 876 (acetate), 1528 (propionate), 2310 (4-C SCFA and $\beta$-hydroxybutyrate), 2838 (5-C SCFA), 1368 (lactate) and 2001 (amino acids) kJ ME/mole.

As no significant effects of sampling time were observed on any variables, data were analysed by ANOVA with animal, period and composition of infusion as the main factors, with means per animal, per treatment as the experimental unit. No period effect was evidenced for any variables. Differences between the four treatments were examined by the Student-Newman-Keuls $t$ test. The effects of energy level (treatment $\mathrm{C} v$. A, P and $\mathrm{B}$ ) and of energy composition (treatments A $v$. P, A $v$. B, B $v$. P) were assessed by contrast analysis. Significance was declared at $P<0 \cdot 10$. All analyses were performed using the GLM procedure of SAS (version 6.03 (1988), Statistical Analysis Systems Inc., Cary, NC, USA).

\section{Results}

\section{Digestibility, rumen variables and short-chain fatty acid production rate}

Diet digestibility was similar among the four treatments (Table 2), on average 56.6, 58.5, 57.0 and $52.2 \%$ for DM, organic matter, neutral detergent fibre and acid detergent fibre respectively. Both rumen $\mathrm{pH}$ and osmolality increased with infusions of SCFA (Table 3). The increase in osmolality was similar with A, P and B infusions, from 201 to an average of $307 \mathrm{mosmol} / \mathrm{l}$ for the three infusions of SCFA. Conversely, $\mathrm{pH}$ was higher with the infusions $\mathrm{P}$ and $\mathrm{B}$ (7.16 on average) than with infusion A (6.88). The volume of the rumen liquid phase increased with infusions of SCFA, irrespective of their composition, from 5.50 to an average of 6.84 litres for the three infusions of SCFA. The turnover rate increased with infusion $\mathrm{B}$. The rumen concentration of $\mathrm{NH}_{3}$ decreased from 3.02 to an average of $1.08 \mathrm{mmol} / \mathrm{l}$ for the three infusions of SCFA. The rumen concentrations of acetate, propionate and butyrate increased linearly with their infusion rate $(R 0.91,0.98$ and 0.98 and a slope of $0.62,0.66$ and 0.63 respectively, data not shown). These relationships were similar with or without the data of the control treatment. The molar proportions of acetate: propionate : butyrate in all the SCFA were, as expected, close to $70: 20: 10$ with infusions $C$ and $A, 50: 40: 10$ with infusion $\mathrm{P}$, and $50: 20: 30$ with infusion $\mathrm{B}$. The rumen concentration of isoacids was not significantly modified by infusion of 
Table 2. Diet digestibility of dry matter (DM), organic matter (OM), neutral detergent fibre (NDF) and acid detergent fibre (ADF) $(\%)^{*}$

(Means with standard errors for four ewes)

\begin{tabular}{|c|c|c|c|c|c|c|c|}
\hline & \multirow[b]{2}{*}{ C } & \multicolumn{3}{|c|}{ SCFA infusion† } & \multirow[b]{2}{*}{ SE } & \multicolumn{2}{|c|}{ Contrasts } \\
\hline & & $A$ & $P$ & B & & Level & Composition \\
\hline $\mathrm{DM}$ & 56.4 & 57.9 & 55.4 & $56 \cdot 7$ & 2.1 & NS & NS \\
\hline $\mathrm{OM}$ & 58.4 & $60 \cdot 1$ & 57.4 & 58.2 & 2.0 & NS & NS \\
\hline NDF & $57 \cdot 6$ & $57 \cdot 1$ & $56 \cdot 2$ & 56.9 & 2.2 & NS & NS \\
\hline ADF & 54.9 & 57.1 & 53.6 & 55.0 & 2.7 & NS & NS \\
\hline
\end{tabular}

SCFA, short-chain fatty acid; NS, not significant $(P>0.01)$.

${ }^{*}$ For details of composition of diet see p. 522.

†For details of infusions see p. 522 .

SCFA, and were on average $0.58 \mathrm{mmol} / \mathrm{l}$ for isobutyrate and $0.32 \mathrm{mmol} / \mathrm{l}$ for isovalerate. Conversely, the rumen concentration of valerate increased with infusion of SCFA, and was the highest with infusions $\mathrm{B}$ and $\mathrm{P}$.

The rumen SCFA production rate on the control diet (C), measured in vivo by a continuous infusion of $\left[{ }^{13} \mathrm{C}\right]$ propionate, was 90.0 (SD 7.9), 23.1 (SD 2.1) and $8.8(\mathrm{SD} \mathrm{1.0)} \mathrm{mmol} / \mathrm{h}$ for acetate, propionate and butyrate respectively (Table 3 ).

\section{Arterial concentrations}

The arterial concentrations of acetate, propionate and butyrate increased linearly with their infusion rate (Table 4) $\left(R 0 \cdot 84,0.83\right.$ and 0.98 and a slope of $6 \cdot 1 \times 10^{-3}, 0 \cdot 9 \times 10^{-3}$ and $0.9 \times 10^{-3}$ respectively, data not shown). Conversely, the arterial concentrations of minor SCFA did not vary between treatments. The arterial concentration of $\beta$-hydroxybutyrate was not modified by infusion $\mathrm{A}$, but was decreased by infusion $\mathrm{P}$ and increased by infusion $\mathrm{B}$. The arterial concentrations of $\mathrm{NH}_{3}$ and glucose were similar among treatments, averaging $0.22 \mathrm{mmol} / \mathrm{l}$ blood and $3.51 \mathrm{mmol} / \mathrm{l}$ plasma respectively. Urea concentration decreased with SCFA infusions, irrespective of their composition, from 1.95 to $1.13 \mathrm{mmol} / \mathrm{l}$ blood. Arterial concentration of lactate increased with infusion P. Arterial concentration of NEFA decreased with infusions A and P. SCFA infusions induced a decrease in arterial concentration of AA. The decrease concerned mostly nonessential AA (glutamine, ornithine, glycine and asparagine) but also essential AA (methionine, lysine, arginine) and 3-methylhistidine. It was irrespective of the SCFA infused for most AA, but was more marked for glutamine and less marked for glycine and alanine with infusion $\mathrm{B}$, and less marked for arginine with infusion $\mathrm{A}$.

\section{Portal blood flow and nutrient net fluxes}

The portal blood and plasma flow rates were not affected by treatment, averaging 140 and $106 \mathrm{l} / \mathrm{h}$ respectively (Table 5).

Table 3. Physicochemical variables, ammonia, short-chain fatty acid (SCFA) concentration, molar proportion and production rate in the rumen

(Means with standard errors for four ewes)

\begin{tabular}{|c|c|c|c|c|c|c|c|}
\hline & \multirow[b]{2}{*}{$\mathrm{C}$} & \multicolumn{3}{|c|}{ SCFA infusion $\ddagger$} & \multirow[b]{2}{*}{ SE } & \multicolumn{2}{|c|}{ Contrasts } \\
\hline & & A & $P$ & $\mathrm{~B}$ & & Level & Composition \\
\hline $\mathrm{pH}$ & $6 \cdot 58^{a}$ & $6 \cdot 88^{b}$ & $7 \cdot 13^{c}$ & $7 \cdot 18^{c}$ & 0.05 & *** & ** \\
\hline Osmolality (mosmol/l) & $201^{\mathrm{a}}$ & $305^{b}$ & $317^{b}$ & $299^{b}$ & 8 & $* * *$ & NS \\
\hline Volume (litres) & $5 \cdot 50^{\mathrm{a}}$ & $7 \cdot 23^{a}$ & $6 \cdot 42^{a}$ & $6 \cdot 88^{\mathrm{a}}$ & 0.57 & $\dagger$ & NS \\
\hline Turnover rate $(\% / \mathrm{h})$ & $6 \cdot 02^{\mathrm{a}}$ & $6 \cdot 41^{\mathrm{a}}$ & $8 \cdot 38^{a b}$ & $9 \cdot 67^{b}$ & 0.96 & $\dagger$ & * \\
\hline Ammonia $(\mathrm{mmol} / \mathrm{l})$ & $3.02^{a}$ & $1.74^{b}$ & $0.91^{\mathrm{b}}$ & $0.58^{b}$ & 0.36 & $* *$ & * \\
\hline \multicolumn{8}{|l|}{ SCFA $(\mathrm{mmol} / \mathrm{l})$} \\
\hline Acetate & $37.04^{\mathrm{a}}$ & $65 \cdot 28^{b}$ & $44 \cdot 78^{\mathrm{a}}$ & $39.88^{a}$ & $2 \cdot 35$ & *** & $* * *$ \\
\hline Propionate & $9.55^{\mathrm{a}}$ & $18 \cdot 17^{\mathrm{b}}$ & $39 \cdot 41^{\mathrm{C}}$ & $17 \cdot 12^{\mathrm{b}}$ & 1.41 & $* * *$ & $* * *$ \\
\hline Isobutyrate & $0.54^{\mathrm{a}}$ & $0.58^{\mathrm{a}}$ & $0.64^{\mathrm{a}}$ & $0.55^{\mathrm{a}}$ & 0.04 & NS & NS \\
\hline Butyrate & $3.64^{a}$ & $7 \cdot 90^{\mathrm{b}}$ & $7.54^{\mathrm{b}}$ & $25 \cdot 56^{\mathrm{c}}$ & 0.50 & $* * *$ & $* \star *$ \\
\hline Isovalerate & $0.30^{\mathrm{a}}$ & $0.32^{a}$ & $0.32^{a}$ & $0.34^{a}$ & 0.05 & NS & NS \\
\hline Valerate & $0.25^{\mathrm{a}}$ & $0.29^{a}$ & $0.38^{\mathrm{b}}$ & $0.43^{b}$ & 0.03 & * & * \\
\hline \multicolumn{8}{|c|}{ Molar proportion of SCFA (\%) } \\
\hline Acetate & $72 \cdot 20^{\mathrm{a}}$ & $70 \cdot 53^{\mathrm{a}}$ & $48 \cdot 15^{\mathrm{b}}$ & $47 \cdot 05^{b}$ & 0.01 & *** & $* * *$ \\
\hline Propionate & $18 \cdot 55^{\mathrm{a}}$ & $19 \cdot 65^{\mathrm{a}}$ & $42 \cdot 38^{b}$ & $20 \cdot 55^{a}$ & 0.01 & $* * *$ & $* * *$ \\
\hline Butyrate & $7 \cdot 10^{\mathrm{a}}$ & $8.53^{\mathrm{a}}$ & $8.08^{\mathrm{a}}$ & $30 \cdot 85^{b}$ & 0.01 & *** & $* * *$ \\
\hline \multicolumn{8}{|c|}{ Production rate of SCFA $(\mathrm{mmol} / \mathrm{h})$} \\
\hline Acetate & $90 \cdot 0$ & - & - & - & - & - & - \\
\hline Propionate & $23 \cdot 1$ & - & - & - & - & - & - \\
\hline Butyrate & 8.8 & - & - & - & - & - & - \\
\hline
\end{tabular}

a,b,c Mean values within a row with unlike superscript letters were significantly different $(P<0 \cdot 10)$. ${ }^{\star \star *} P<0.001 ;{ }^{* *} P<0.01 ;{ }^{\star} P<0.05 ; \dagger P<0.10$; NS, not significant $(P>0.10)$; - , not determined. $\ddagger$ For details of infusions see p. 522 . 
Table 4. Arterial concentrations of nutrients ( $\mathrm{mmol} / \mathrm{l}$ ) (Means with standard errors for four ewes)

\begin{tabular}{|c|c|c|c|c|c|c|c|}
\hline & \multirow[b]{2}{*}{$\mathrm{C}$} & \multicolumn{3}{|c|}{ SCFA infusion $\ddagger$} & \multirow[b]{2}{*}{ SE } & \multicolumn{2}{|c|}{ Contrasts } \\
\hline & & $A$ & $\mathrm{P}$ & B & & Level & Composition \\
\hline \multicolumn{8}{|l|}{ Blood } \\
\hline Acetate & $0.587^{a}$ & $0 \cdot 814^{\mathrm{b}}$ & $0.592^{a}$ & $0.527^{a}$ & 0.020 & $t$ & $* * *$ \\
\hline Propionate & $0.011^{a}$ & $0.020^{\mathrm{a}}$ & $0.051^{\mathrm{b}}$ & $0.023^{a}$ & 0.004 & $* *$ & $* *$ \\
\hline Isobutyrate & $0.003^{a}$ & $0.003^{a}$ & $0.004^{a}$ & $0.002^{a}$ & 0.001 & NS & NS \\
\hline Butyrate & $0.002^{\mathrm{a}}$ & $0.005^{a}$ & $0.005^{a}$ & $0.031^{b}$ & 0.001 & $* * *$ & $* * *$ \\
\hline Isovalerate & $0.001^{a}$ & $0.001^{\mathrm{a}}$ & $0.001^{\mathrm{a}}$ & $0.001^{\mathrm{a}}$ & $<0.001$ & NS & $\dagger$ \\
\hline Valerate & $0.001^{a}$ & $0.001^{a}$ & $0.001^{a}$ & $0.001^{a}$ & $<0.001$ & NS & NS \\
\hline$\beta$-Hydroxybutyrate & $0.244^{a}$ & $0.237^{a}$ & $0 \cdot 107^{\mathrm{b}}$ & $0.428^{c}$ & 0.020 & NS & $* * *$ \\
\hline Ammonia & $0.219^{a}$ & $0 \cdot 194^{a}$ & $0.206^{a}$ & $0.237^{a}$ & 0.032 & NS & NS \\
\hline Urea & $1.952^{\mathrm{a}}$ & $1 \cdot 162^{\mathrm{a}}$ & $0.979^{a}$ & $1.269^{\mathrm{a}}$ & 0.307 & * & NS \\
\hline Amino acids & $2 \cdot 734^{a}$ & $2 \cdot 235^{\mathrm{b}}$ & $2 \cdot 220^{\mathrm{b}}$ & $2.482^{\mathrm{ab}}$ & 0.129 & * & NS \\
\hline \multicolumn{8}{|l|}{ Plasma } \\
\hline Glucose & $3.469^{a}$ & $3.525^{a}$ & $3.622^{a}$ & $3 \cdot 410^{\mathrm{a}}$ & 0.128 & NS & NS \\
\hline Lactate & $0.367^{a}$ & $0.568^{a}$ & $0.873^{b}$ & $0.424^{a}$ & 0.106 & $\dagger$ & * \\
\hline NEFA & $0.377^{\mathrm{a}}$ & $0.272^{b}$ & $0.236^{\mathrm{b}}$ & $0.351^{a}$ & 0.024 & & ** \\
\hline \multicolumn{8}{|l|}{ Blood } \\
\hline Threonine & $0.082^{a}$ & $0.058^{a}$ & $0.077^{\mathrm{a}}$ & $0.071^{a}$ & 0.011 & NS & NS \\
\hline Valine & $0.178^{a}$ & $0.159^{a}$ & $0 \cdot 161^{\mathrm{a}}$ & $0 \cdot 158^{\mathrm{a}}$ & 0.015 & NS & NS \\
\hline Methionine & $0.013^{a}$ & $0.011^{a}$ & $0.011^{\mathrm{a}}$ & $0.011^{a}$ & 0.001 & $*$ & NS \\
\hline Isoleucine & $0.085^{\mathrm{a}}$ & $0.073^{a}$ & $0.069^{a}$ & $0.081^{a}$ & 0.005 & NS & NS \\
\hline Leucine & $0 \cdot 105^{\mathrm{a}}$ & $0.091^{\mathrm{a}}$ & $0.094^{a}$ & $0.094^{\mathrm{a}}$ & 0.008 & NS & NS \\
\hline Phenylalanine & $0.037^{\mathrm{a}}$ & $0.035^{\mathrm{a}}$ & $0.037^{a}$ & $0.036^{\mathrm{a}}$ & 0.002 & NS & NS \\
\hline Lysine & $0 \cdot 184^{a}$ & $0 \cdot 125^{\mathrm{a}}$ & $0 \cdot 127^{a}$ & $0.135^{\mathrm{a}}$ & 0.018 & * & NS \\
\hline Histidine & $0.082^{a}$ & $0.069^{a}$ & $0.071^{\mathrm{a}}$ & $0.066^{\mathrm{a}}$ & 0.008 & NS & NS \\
\hline Arginine & $0.049^{a}$ & $0.046^{a}$ & $0.038^{b}$ & $0.038^{b}$ & 0.002 & $* *$ & $*$ \\
\hline Essential AA & $0 \cdot 816^{a}$ & $0.667^{b}$ & $0.685^{b}$ & $0.688^{\mathrm{b}}$ & 0.054 & $\dagger$ & NS \\
\hline Aspartate & $0.021^{a}$ & $0.025^{\mathrm{a}}$ & $0.026^{\mathrm{a}}$ & $0.023^{\mathrm{a}}$ & 0.003 & NS & NS \\
\hline Serine & $0.073^{a}$ & $0.066^{a}$ & $0.072^{a}$ & $0.079^{\mathrm{a}}$ & 0.010 & NS & NS \\
\hline Asparagine & $0.043^{a}$ & $0.035^{\mathrm{b}}$ & $0.037^{\mathrm{ab}}$ & $0.038^{\mathrm{ab}}$ & 0.002 & $*$ & NS \\
\hline Glutamate & $0.208^{a}$ & $0.230^{\mathrm{a}}$ & $0 \cdot 199^{a}$ & $0.225^{\mathrm{a}}$ & 0.017 & NS & NS \\
\hline Glutamine & $0.219^{a}$ & $0.162^{b}$ & $0.153^{b c}$ & $0.129^{c}$ & 0.009 & $* * *$ & * \\
\hline Glycine & $0.971^{a}$ & $0.702^{\mathrm{b}}$ & $0.673^{b}$ & $0.955^{\mathrm{a}}$ & 0.069 & * & * \\
\hline Alanine & $0.157^{a}$ & $0 \cdot 177^{a}$ & $0.198^{\mathrm{a}}$ & $0.159^{a}$ & 0.012 & NS & * \\
\hline Tyrosine & $0.041^{a}$ & $0.035^{\mathrm{a}}$ & $0.040^{\mathrm{a}}$ & $0.037^{\mathrm{a}}$ & 0.002 & NS & $t$ \\
\hline Ornithine & $0.176^{\mathrm{a}}$ & $0 \cdot 128^{a}$ & $0 \cdot 125^{\mathrm{a}}$ & $0.138^{\mathrm{a}}$ & 0.014 & * & NS \\
\hline Cysteine & $0.009^{a}$ & $0.011^{a}$ & $0.010^{\mathrm{a}}$ & $0.011^{\mathrm{a}}$ & 0.002 & NS & NS \\
\hline Nonessential AA & $1.918^{a}$ & $1.568^{\mathrm{b}}$ & $1.535^{\mathrm{b}}$ & $1.793^{\mathrm{ab}}$ & 0.096 & * & $\dagger$ \\
\hline 3-Methylhistidine & $0.054^{a}$ & $0.043^{b}$ & $0.039^{b}$ & $0.042^{b}$ & 0.002 & $* * *$ & NS \\
\hline
\end{tabular}

SCFA, short-chain fatty acid; NEFA, non-esterified fatty acid; AA, amino acid.

a,b,c Mean values within a row with unlike superscript letters were significantly different $(P<0 \cdot 10)$. ${ }^{\star * \star} P<0.001 ;{ }^{\star *} P<0.01 ;{ }^{*} P<0.05 ; \dagger P<0.10 ; \mathrm{NS}$, not significant $(P>0.10)$.

$\ddagger$ For details of infusions see p. 522 .

The portal net release of acetate and propionate increased linearly with their infusion rate $(R 0.66$ and 0.87 and a slope of 0.74 and 0.67 respectively, data not shown). Linear and curvilinear regressions both indicated a portal recovery of 0.31 for butyrate $(R 0.96$ and 0.92 respectively, data not shown). The relationships between infusion rate and portal net release were the same with or without data from the control treatment, except for acetate, for which the closest relationship $(R \quad 0.74)$ was observed without data from the control treatment (slope 0.84 ). Net portal release of valerate increased with SCFA infusions but this was significant only with infusion B. Net fluxes of isobutyrate, isovalerate and NEFA did not vary between treatments, averaging $0.41,0.27$ and $-0.59 \mathrm{mmol} / \mathrm{h}$ respectively. Net release of $\beta$-hydroxybutyrate and net uptake of glucose increased with SCFA infusions, irrespective of their composition, from 2.88 to $4.60 \mathrm{mmol} / \mathrm{h}$ for $\beta$-hydroxybutyrate and from 10.77 to $14.53 \mathrm{mmol} / \mathrm{h}$ for glucose. Net release of $\mathrm{NH}_{3}$ and net uptake of urea decreased with SCFA infusions, from 8.32 to 4.64 and from 10.55 to $6.93 \mathrm{mmol} / \mathrm{h}$ respectively, irrespective of the SCFA infused. Net release of lactate decreased with infusion B. Portal net fluxes of AA indicated a net uptake of AA by PDV with the control treatment, mostly due to nonessential AA (glycine, glutamate, glutamine). The net uptake of AA decreased with SCFA infusions, and shifted to a net release with infusions $\mathrm{A}$ and $P$. This was related to an increase in net release of essential AA (isoleucine, leucine) and tyrosine and to a decrease in net uptake of nonessential AA such as glutamate but not of glutamine. For all AA, net fluxes were similar with infusions $\mathrm{A}$ and P. Conversely, a lower net release of most essential (particularly isoleucine, leucine, phenylalanine), and nonessential (particularly asparagine, tyrosine) AA, and a lower net uptake of glutamine were observed with infusion B.

Summation of net portal energy fluxes increased with SCFA infusions, irrespective of their composition, from 
Table 5. Portal flows $(\mathrm{l} / \mathrm{h})$, net fluxes of nutrients $(\mathrm{mmol} / \mathrm{h})$ and energetic summation $(\mathrm{kJ} / \mathrm{h})$

(Means with standard errors for four ewes)

\begin{tabular}{|c|c|c|c|c|c|c|c|}
\hline & \multirow[b]{2}{*}{$\mathrm{C}$} & \multicolumn{3}{|c|}{ SCFA infusion $\ddagger$} & \multirow[b]{2}{*}{ SE } & \multicolumn{2}{|c|}{ Contrasts } \\
\hline & & $A$ & $\mathrm{P}$ & B & & Level & Composition \\
\hline Blood flow & $135 \cdot 4^{\mathrm{a}}$ & $149 \cdot 0^{\mathrm{a}}$ & $136 \cdot 4^{\mathrm{a}}$ & $139.7^{\mathrm{a}}$ & $10 \cdot 0$ & NS & NS \\
\hline Plasma flow & $104 \cdot 9^{a}$ & $113 \cdot 8^{\mathrm{a}}$ & $102 \cdot 0^{\mathrm{a}}$ & $104 \cdot 6^{\mathrm{a}}$ & 8.0 & NS & NS \\
\hline \multicolumn{8}{|l|}{ Net fluxes } \\
\hline Acetate & $58 \cdot 73^{a}$ & $86 \cdot 38^{b}$ & $52.56^{\mathrm{a}}$ & $49 \cdot 36^{a}$ & $7 \cdot 36$ & NS & ** \\
\hline Propionate & $15 \cdot 46^{a}$ & $24.86^{\mathrm{b}}$ & $47.32^{c}$ & $23.02^{b}$ & $2 \cdot 31$ & $* * *$ & $* * *$ \\
\hline Isobutyrate & $0.39^{a}$ & $0.40^{\mathrm{a}}$ & $0.42^{\mathrm{a}}$ & $0.43^{a}$ & 0.06 & NS & NS \\
\hline Butyrate & $0.58^{a}$ & $2.02^{a}$ & $1.84^{\mathrm{a}}$ & $10 \cdot 77^{\mathrm{b}}$ & 0.78 & $\star \star \star *$ & $* * *$ \\
\hline Isovalerate & $0.24^{a}$ & $0.29^{a}$ & $0.28^{a}$ & $0.25^{\mathrm{a}}$ & 0.05 & NS & NS \\
\hline Valerate & $0.08^{a}$ & $0 \cdot 10^{a}$ & $0.12^{\mathrm{a}}$ & $0.22^{b}$ & 0.02 & * & $* *$ \\
\hline$\beta$-Hydroxybutyrate & $2.88^{\mathrm{a}}$ & $5 \cdot 17^{b}$ & $4.06^{\mathrm{ab}}$ & $4.56^{\mathrm{ab}}$ & 0.58 & * & NS \\
\hline Glucose & $-10 \cdot 77^{a}$ & $-16 \cdot 06^{b}$ & $-12 \cdot 65^{a b}$ & $-14.89^{a b}$ & 1.33 & * & NS \\
\hline Lactate & $10 \cdot 35^{\mathrm{ab}}$ & $10 \cdot 15^{\mathrm{ab}}$ & $11.77^{\mathrm{a}}$ & $5.07^{b}$ & 1.63 & NS & * \\
\hline NEFA & $-0.27^{a}$ & $0 \cdot 36^{a}$ & $1 \cdot 16^{a}$ & $0.05^{a}$ & 0.83 & NS & NS \\
\hline Ammonia & $8 \cdot 32^{a}$ & $5 \cdot 46^{a b}$ & $3.35^{\mathrm{b}}$ & $5 \cdot 11^{\mathrm{ab}}$ & 1.28 & * & NS \\
\hline Urea & $-10.55^{a}$ & $-8.09^{a}$ & $-5 \cdot 88^{a}$ & $-6 \cdot 83^{a}$ & 1.70 & $t$ & NS \\
\hline Amino acids & $-7 \cdot 10^{a}$ & $5 \cdot 72^{a}$ & $3 \cdot 23^{a}$ & $-1.54^{a}$ & 3.76 & $\dagger$ & NS \\
\hline Energetic summation & $99 \cdot 85^{a}$ & $158.50^{b}$ & $159 \cdot 03^{b}$ & $126 \cdot 11^{\mathrm{ab}}$ & $13 \cdot 74$ & $* * *$ & NS \\
\hline Threonine & $0.22^{\mathrm{a}}$ & $0.47^{a}$ & $0.47^{a}$ & $0.15^{a}$ & 0.14 & NS & NS \\
\hline Valine & $-0.03^{a}$ & $0.55^{a}$ & $0.51^{a}$ & $0 \cdot 19^{a}$ & 0.24 & NS & NS \\
\hline Methionine & $0.06^{\mathrm{a}}$ & $0.13^{a}$ & $0.09^{a}$ & $0.07^{a}$ & 0.02 & NS & $\dagger$ \\
\hline Isoleucine & $0.04^{a}$ & $0.46^{b}$ & $0.40^{\mathrm{b}}$ & $0.17^{a}$ & 0.07 & $* *$ & * \\
\hline Leucine & $0 \cdot 12^{\mathrm{a}}$ & $0.74^{b}$ & $0.74^{b}$ & $0.26^{a}$ & 0.12 & $* *$ & * \\
\hline Phenylalanine & $0.30^{a}$ & $0.44^{a}$ & $0.49^{a}$ & $0.14^{\mathrm{a}}$ & $0 \cdot 10$ & NS & * \\
\hline Lysine & $0.09^{\mathrm{a}}$ & $1.52^{\mathrm{a}}$ & $0.60^{a}$ & $-0 \cdot 32^{a}$ & 0.61 & NS & $\dagger$ \\
\hline Histidine & $-0 \cdot 19^{a}$ & $0.04^{a}$ & $0 \cdot 18^{a}$ & $-0.27^{a}$ & 0.17 & NS & $\dagger$ \\
\hline Arginine & $-0.01^{a}$ & $0.01^{a}$ & $0.27^{a}$ & $-0.22^{a}$ & 0.18 & NS & $\dagger$ \\
\hline Essential AA & $0.60^{\mathrm{a}}$ & $4 \cdot 36^{\mathrm{b}}$ & $3.74^{b}$ & $0 \cdot 19^{a}$ & 0.96 & $\dagger$ & $*$ \\
\hline Aspartate & $-0.05^{a}$ & $-0.21^{a}$ & $0.50^{a}$ & $-0.06^{a}$ & 0.34 & NS & NS \\
\hline Serine & $0.74^{\mathrm{a}}$ & $1.04^{\mathrm{a}}$ & $0.86^{\mathrm{a}}$ & $0.48^{a}$ & 0.19 & NS & $t$ \\
\hline Asparagine & $0.45^{\mathrm{a}}$ & $1.03^{\mathrm{a}}$ & $0.63^{a}$ & $0 \cdot 10^{a}$ & 0.25 & NS & * \\
\hline Glutamate & $-3 \cdot 87^{a}$ & $-0.99^{b}$ & $-1.29^{b}$ & $-1.06^{b}$ & 0.51 & $* *$ & NS \\
\hline Glutamine & $-1 \cdot 76^{\mathrm{ab}}$ & $-2 \cdot 23^{a b}$ & $-3 \cdot 30^{\mathrm{b}}$ & $-1 \cdot 26^{a}$ & 0.47 & NS & * \\
\hline Glycine & $-3.90^{a}$ & $0.26^{a}$ & $0.05^{\mathrm{a}}$ & $-1 \cdot 13^{a}$ & 1.78 & NS & NS \\
\hline Alanine & $1 \cdot 19^{a}$ & $1.87^{\mathrm{a}}$ & $1.67^{\mathrm{a}}$ & $0.90^{\mathrm{a}}$ & 0.38 & NS & NS \\
\hline Tyrosine & $0.08^{a}$ & $0.33^{b}$ & $0.25^{a b}$ & $0.11^{a}$ & 0.06 & $*$ & * \\
\hline Ornithine & $-0.55^{\mathrm{a}}$ & $0.16^{a}$ & $0.04^{a}$ & $0 \cdot 13^{a}$ & 0.35 & NS & NS \\
\hline Cysteine & $-0.03^{a}$ & $0.09^{a}$ & $0.07^{a}$ & $0.05^{a}$ & 0.11 & NS & NS \\
\hline Nonessential AA & $-7 \cdot 70^{\mathrm{a}}$ & $1 \cdot 36^{b}$ & $-0.51^{b}$ & $-1.73^{b}$ & $3 \cdot 18$ & $\dagger$ & NS \\
\hline
\end{tabular}

SCFA, short-chain fatty acid; NEFA, non-esterified fatty acid.

a,b,c Mean values within a row with unlike superscript letters were significantly different $(P<0 \cdot 10)$

${ }^{\star * *} P<0.001 ;{ }^{* *} P<0.01 ;{ }^{*} P<0.05 ; \dagger P<0.10$; NS, not significant $(P>0.10)$.

$\ddagger$ For details of infusions see p. 522 .

$99.9 \mathrm{~kJ} / \mathrm{h}$ with the control treatment to an average of $147.9 \mathrm{~kJ} / \mathrm{h}$ with treatments A, P and B (Table 5).

\section{Discussion}

Due to the low $\mathrm{N}$ content of the diet in each treatment, it is of importance to emphasize the lack of period effect on any variable measured, and particularly on AA arterial concentrations and portal net fluxes. Together with the normal comportment of animals, this suggests that no interactive effect of recovery from surgery occurred.

\section{Digestibility, rumen variables and short-chain fatty acid production rate}

To ensure a normal rumen motility and rumination, several authors have used semi-fasted animals (Krehbiel et al. 1992; Seal \& Parker, 1994; Kristensen et al. 1996) instead of total intragastric nutrition (Weekes \& Webster, 1975; Gross et al. $1990 a, b)$ in order to study the PDV metabolism. A main concern in this situation is whether the basal production of rumen SCFA is the same in all treatments. In the present study, infusions were maintained for $7 \mathrm{~d}$ in order to control the digestibility of the diet. Digestibility remained constant, suggesting a constant basal production rate of SCFA in all treatments. In agreement with this suggestion, the rumen concentration of isoacids, which were not infused, remained constant. The increase in $\mathrm{pH}$ induced by infusions of SCFA may thus not have altered the cellulolytic microbial ecosystem. The amount of microbial $\mathrm{N}$ associated with particles in the rumen (Shriver et al. 1986) and the microbial fibrolytic activity (Mould \& Ørskov, 1983/84) were shown to be stable with $\mathrm{pH}$ varying between $7 \cdot 0$ and $6 \cdot 2$.

It can be assumed that the small increase in $\mathrm{pH}$ induced by buffer infused concomitantly with SCFA may not have modified SCFA fractional disappearance from the lumen 
since it is relatively stable at a $\mathrm{pH}$ of between 6.0 and 7.5 (Bueno, 1972). Conversely, the increase in osmolality from 200 to $300 \mathrm{mosmol} / \mathrm{l}$ may have decreased the SCFA absorption rate. However, according to the equations reported by Tabaru et al. (1990), this decrease in absorption rate may only be $3 \% / \mathrm{h}$ for both acetate, propionate and butyrate. Moreover, the turnover rate of the rumen liquid phase was not strongly modified by infusions of SCFA. In consequence, the relationships between the rumen infusion rate and rumen concentration of infused SCFA were similar with and without the data of the control treatment. The slopes of these relationships indicated, in agreement with Kristensen et al. (1996), similar rumen disappearance for acetate, propionate and butyrate, assuming a steady state in the rumen. This is in agreement with the equal rumen disappearance rates for these three SCFA observed at rumen $\mathrm{pH}$ around 7 by Dijkstra et al. (1993).

Assuming an equal rumen disappearance rate for these three SCFA, their rumen production rate, estimated by $\left[{ }^{13} \mathrm{C}\right]$ propionate isotope-dilution technique, and expressed in $\mathrm{mmol} / \mathrm{g} \mathrm{DM}$ intake, were $4.5,1.2$ and 0.4 for acetate, propionate and butyrate respectively. These values are close to those measured by both $\left[{ }^{14} \mathrm{C}\right]$ acetate, propionate and butyrate infusions, in sheep fed on a forage diet at a comparable intake level to ours (Weller et al. 1967). Hogan \& Weston (1967) reported a close and linear relationship between organic matter digested and total SCFA rumen production rate in sheep fed ad libitum, with a slope of $9.2 \mathrm{mmol}$ SCFA/g organic matter digested. This value is close to that measured in the present study $(11.4 \mathrm{mmol}$ SCFA produced/g organic matter digested). According to Huhtanen \& Jaakkola (1995), the ratio intercept: slope given by the linear relationship between the SCFA infusion rate and rumen concentration may reflect the rumen SCFA production rate. With our data, this calculation may underestimate the SCFA production rate compared with the isotope dilution technique $(63 v .90,15 v .23$ and $6 v .9 \mathrm{mmol} / \mathrm{h}$ for acetate, propionate and butyrate respectively). Unfortunately, no other direct comparison between these two techniques of measurement of the SCFA production rate has been made.

\section{Portal blood flow}

As previously reported (Huntington et al. 1983; Gross et al. 1990a,b; Krehbiel et al. 1992; Seal \& Parker, 1994; Kristensen et al. 1996), portal blood flow was not modified by rumen infusion of SCFA. In conventionally-fed animals, it has been shown to vary positively with ME intake (for reviews see Huntington, 1990; Rémond et al. 1998) but variations appear lower under $v$. above maintenance (Lomax \& Baird, 1983; P. Nozière, D. Rémond, L. Bernard \& M. Doreau, unpublished results). It can be expected that the amount of energy infused in fasted or semi-fasted animals is insufficient to induce changes in portal blood flow, or that the filling of the digestive tract is a predominant factor regulating portal blood flow, explaining the lack of variation in infused animals. In agreement with this suggestion, an analysis of sixty data sets from seventeen available trials in which at least two levels of the same diet were fed to sheep or cattle showed that for the same variation in ME intake (in $\mathrm{MJ} / \mathrm{d}$ per kg live weight ${ }^{0.75}$ ), the increase in portal blood flow (in $1 / \mathrm{d}$ per $\mathrm{kg}$ live weight ${ }^{0.75}$ ) is more marked with high-forage (forage: concentrate ratio $>0.7$ ) than with high-concentrate (forage : concentrate ratio $<0.7)$ diets $(R$. Bernard and P. Nozière, unpublished results). This may be related to a higher filling of the digestive tract with highforage diets. The slopes of these relationships (173 and 96 respectively) are consistent with the one (134) reported by Rémond et al. (1998) from data obtained on sheep, without regard to the forage: concentrate ratio. However, the various dietary chemical and physical factors controlling gut development and blood flow in PDV have to be studied more clearly because they vary between the various organs in the digestive tract, and even between the various layers of the same organ (Barnes et al. 1986; Nozière et al. 1999a).

\section{Short-chain fatty acids and $\beta$-hydroxybutyrate}

In this present experiment, 16,33 and $70 \%$ of infused acetate, propionate and butyrate respectively, did not reach the portal vein. These values are close to the lowest values found in the literature, 18 to $33 \%$ for acetate, 30 to $70 \%$ for propionate, 74 to $90 \%$ for butyrate, as reviewed by Rémond et al. (1995). It may be suggested that metabolism of SCFA in the ruminal wall was low due to the underfed state of animals.

The portal net release of $\beta$-hydroxybutyrate did not increase with the butyrate infusion rate, averaging $4.6 \mathrm{mmol} / \mathrm{h}$ with the three SCFA infusions. A limited portal net release of ketone bodies following rumen butyrate infusion has already been reported (Krehbiel et al. 1992; Kristensen et al. 1996). Since it may result from both net release from the stomachs and net uptake by mesenteric-drained viscera (Reynolds \& Huntington, 1988), the limited portal release of $\beta$-hydroxybutyrate may be attributed to both a limited enzymic capacity or availability of cofactors for ketogenesis from butyrate in the stomachs, and to an increased uptake of $\beta$-hydroxybutyrate by mesenteric-drained viscera associated with the increase in arterial concentration of $\beta$-hydroxybutyrate with the high-butyrate infusion.

\section{Glucose and lactate}

Sparing glucose is a major mechanism involved in the adaptation of ruminants to undernutrition (Chilliard et al. 1998). Indeed, the arterial concentration of glucose did not vary between treatments, indicating that glucose homeostasis was affected neither by the undernutrition, nor by the composition of energy infused. In contrast with our results, several authors reported that increasing rumen butyrate supply induced a decrease in glucose arterial concentration (Krehbiel et al. 1992; Huhtanen et al. 1993; Miettinen \& Huhtanen, 1996). This decrease in glycaemia was not related to hyperinsulinaemia, but may be related to a depressive effect of butyrate on gluconeogenesis from propionate, as observed in isolated sheep hepatocytes by Demigné et al. (1991). This is consistent with Eisemann \& Huntington (1994) who showed no effect of hyperinsulinaemia on propionate removal from the liver. In the present study, the lack of variation in glycaemia may be due to the much lower amount of butyrate infused, which may be too low to depress the utilization of propionate for gluconeogenesis 
in the liver. Although arterial supply was unchanged, the net uptake of glucose by PDV was higher with infusions of SCFA than with the control treatment. This may be due to an increased oxidation of glucose, which can be related to an insulinaemic response.

The higher arterial concentration of lactate in highpropionate infused ewes is in agreement with Casse et al. (1994) who reported that propionate infusion in the mesenteric vein increased net output of lactate from the liver in lactating cows. This may be related more to an increased production of lactate from propionate in the liver, than to a decrease in hepatic net uptake of lactate, since of the glucose precursors, lactate appears to have the lowest priority in fed ruminants (Reynolds, 1995). Lactate reaching the portal vein can be from various origins (lumen or artery) and precursors (propionate (Leng et al. 1967) or glucose (Weekes \& Webster, 1975)). With the diet used in the present work, lactate absorbed from the lumen can be assumed as negligible. As observed by others (Casse et al. 1994; Seal \& Parker, 1994), net portal output of lactate did not increase with the infusion of propionate, suggesting that lactate production from propionate did not increase in the ruminal wall or that uptake of lactate in the wall of mesenteric-drained viscera increased, in relation to the increase in arterial concentration of lactate. The decrease in portal net output of lactate observed with the highbutyrate infusion suggests an inhibitory effect of butyrate on lactate synthesis. This is in agreement with others (for review see Rémond et al. 1995) who reported that propionate activation to propionyl-coA is severely depressed in vitro in the presence of butyrate. Thus, it seems that lactate production from propionate in PDV is not negligible but may be limited.

\section{Non-esterified fatty acids}

During fasting, the oxidation of NEFA released by adipose tissue allows the sparing of glucose and AA as oxidative fuels (Chilliard et al. 1998). An extensive use of NEFA by peripheral tissues is thus observed in underfed ruminants. However, little data on net fluxes of NEFA through PDV are available. Krehbiel et al. (1992) observed no changes in portal net release of NEFA by increasing the rumen infusion rate of butyrate in steers. In the present study, although arterial concentration of NEFA was higher in non-infused ewes, reflecting lipolysis, net flux of NEFA across PDV did not differ from 0 with the four treatments, suggesting, in agreement with Lindsay (1993), that NEFA are not a direct source of energy for PDV.

\section{Amino acids}

Infusion of SCFA decreased arterial concentration of AA and particularly of glutamine and 3-methylhistidine. This may reflect a higher net release of AA by peripheral tissues in non-infused ewes, allowing provision of AA for maintenance of vital processes in other tissues. A decrease in arterial AA with infusion of SCFA was also obtained for $\alpha$-amino-N with feeding sodium propionate (Harmon \& Avery, 1987) or infusion of butyrate (Krehbiel et al. 1992), without any change in splanchnic net flux of
$\alpha$-amino-N (Krehbiel et al. 1992). These results suggest that infusions of SCFA increased the uptake of AA by peripheral tissues. Similarly, a decrease in portal net release of AA with feeding propionate or infusing butyrate was reported by Harmon \& Avery (1987) and Krehbiel et al. (1992), indicating that infusions of SCFA increased the uptake of AA in PDV tissues as in peripheral tissues. This may be related to an insulinaemic response.

Net portal flux of AA showed a net uptake of AA by PDV in non-infused animals. Above maintenance, the portal net appearance of AA has been shown to decrease linearly when the level of intake of the same diet decreases (Huntington \& Prior, 1985). More recently, we observed that the portal net flux of AA decreases more drastically under than above maintenance, reaching from net appearance above maintenance to net uptake in underfed animals (Nozière et al. $1999 b$ ). This suggests that in the underfed state, AA have to be used to sustain energy requirements of PDV, which is consistent with the results of the present study. The net uptake of AA with the control treatment was mostly due to nonessential AA, and particularly glutamate, glycine and glutamine. Net uptake of glutamate and glutamine by PDV is classically observed in ruminants and other species (for review see Huntington, 1990). Because amino groups released from oxidation of glutamate and glutamine are transmitted to alanine, serine and glycine, the net uptake of glycine appears surprising. This result suggests that glycine may be used by PDV in ewes submitted to energy underfeeding. Similarly, net portal flux of glycine has been shown to shift from net release to net uptake in ewes fed on 1.3 and 0.5 energy maintenance requirements respectively (Nozière et al. 1999b).

SCFA infusions decreased net uptake of total AA (except glutamine) by PDV, allowing a net portal release of total AA with high-acetate and high-propionate infusions. The main AA involved were glutamate, for which uptake was decreased, and isoleucine, leucine and tyrosine, for which net portal release was increased. This may be related to a decrease in the oxidation of isoleucine and leucine by PDV. Conversely, a decrease in portal net release of $\alpha$-amino-N with feeding propionate or infusing butyrate was reported by Harmon \& Avery (1987) and Krehbiel et al. (1992), indicating an increased use of AA by PDV. However, in these experiments, the basal diet covered more than energy maintenance requirements, in contrast with the basal diet used in our trial. According to the increase in rumen $\mathrm{pH}$ and osmolality and the decrease in rumen $\mathrm{NH}_{3}$ concentration induced in the present experiment by infusions of SCFA, it can be expected that microbial synthesis was increased due to the increase in energy available for microbes with infusions of SCFA. This could have provided a higher amount of digestible AA from microbial origin in the small intestine, explaining the shift from portal net uptake of AA with the control treatment to net release in ewes receiving SCFA. Moreover, compared with infusions $\mathrm{A}$ and $\mathrm{P}$, net release of essential AA and net uptake of glutamine were reduced with infusion B, suggesting a shift from glutamine to essential AA utilization by PDV with high-butyrate-producing diets. This may be related to a higher stimulating effect of butyrate, compared with acetate and propionate, on epithelial cell proliferation (Sataka \& Tamate, 1978). 


\section{Ammonia and urea}

As discussed earlier, infusion of SCFA may have improved the microbial synthesis in the rumen. In association with the low $\mathrm{N}$ level of the diet, this may explain the observed decrease in rumen concentration of $\mathrm{NH}_{3}$. Since $\mathrm{NH}_{3}$ is preferentially absorbed from the rumen by simple diffusion (Bergman, 1990), the decrease in portal net release of $\mathrm{NH}_{3}$ with SCFA infusions was related to the decrease in the rumen $\mathrm{NH}_{3}$ concentration. This may contribute to the decrease in urea synthesis in the liver, as shown by the drop in the arterial urea. Consequently, the transfer of urea from arterial blood to lumen was decreased.

\section{Energetic summation of portal net release}

In the present experiment, $61 \%$ of ME intake was released in the portal vein with the control treatment. This value is in agreement with Huntington (1990) and Lindsay (1993) who reviewed the partition of $\mathrm{ME}$ intake during absorption in conventionally fed cattle or sheep: $52-82 \%$ are released in the portal vein as SCFA, ketone bodies, lactate and AA, $11-24 \%$ are oxidized during absorption, the remaining $(8-37 \%)$ corresponding to heat of fermentation, absorption of long-chain fatty acids, nucleic acids and peptides. However, there is little data on energetic summation of portal net release in infused animals, since most studies based on intragastric infusions focused on only few metabolites. Gross et al. (1990b), studying growing lambs maintained by total enteral infusions, reported that substitution of propionate by an isoenergetic abomasum infusion of glucose decreased the amount of ME released in the portal vein from 84 to $64 \%$. This may be related to the energy cost of glucose absorption. From data from Huntington et al. (1983), it can be calculated that $82 \%$ of the ME $(246 \mathrm{~kJ} / \mathrm{h})$ infused as acetate into the rumen of cows fed above maintenance was released in the portal vein as SCFA and lactate. Conversely, infusion of $250 \mathrm{mmol} / \mathrm{h}$ of butyrate (i.e. $578 \mathrm{~kJ} / \mathrm{h}$ ) in the rumen of steers fed at $1.25 \times$ net energy maintenance requirements did not modify the amount of energy released in the portal vein (Krehbiel et al. 1992), suggesting that all energy infused was used by PDV during absorption. This may be related to a stimulating effect of SCFA, particularly butyrate, on epithelial cell proliferation, as observed in vivo in adult ruminants (Sakata \& Tamate, 1978).

Of major concern in the present study is whether the composition of SCFA may modulate the amount of energy retained by the digestive tract. Our data show that the composition of SCFA does not significantly modify the amount of energy recovered in the portal vein, averaging 67, 64 and $50 \%$ of the total ME intake infused for treatments A, P and $\mathrm{B}$ respectively. Although the portal recovery of ME tended to be lower with treatment $\mathrm{B}$, it can be expected that SCFA may not induce higher PDV energy expenditure with high-soluble-carbohydrate diets than with high-forage or high-cereal diets. Indeed, in most cases, high-solublecarbohydrate diets rarely induce such a high molar proportion of butyrate in the rumen as in this experiment $(30 \%)$. Moreover, the partition of energy between SCFA and their metabolites ( $\beta$-hydroxybutyrate, lactate) on one hand, and AA on the other hand, was similar with all treatments, net portal flux of AA contributing less than $7 \%$ of the net portal flux of ME, due to the $\mathrm{N}$ underfeeding.

In conclusion, $60 \%$ of ME infused into the rumen as SCFA was recovered in the portal vein, and the composition of SCFA did not significantly modify the amount of energy supplied to portal blood. However, with high-butyrate infusion, compared with high-acetate or -propionate infusions, PDV may reduce its consumption of glutamine but increase its consumption of essential AA. This may be related to the trophic effect of butyrate on the digestive mucosa.

\section{Acknowledgements}

The authors wish to thank J. Lefaivre for surgery, M. Fabre, A. Ollier, A. Combeau and the staff of 'Les Cèdres' for animal care and help with sampling, G. Sauvage, J. Chabrot and M. Tourret for analyses, and Professor H. Dumon for valuable advice on SCFA measurements.

\section{References}

Barnes RJ, Comline RS \& Dobson A (1986) The control of splanchnic blood flow. In Control of Digestion and Metabolism in Ruminants, pp. 41-59 [LP Milligan, WL Grovum and A Dobson, editors]. Englewood Cliffs, NJ: Prentice Hall.

Barnouin J, El Idilbi N, Chilliard Y, Chacornac JP \& Lefaivre R (1986) Micro-dosage automatisé sans déprotéinisation du 3hydroxybutyrate plasmatique chez les bovins (Automated micro-analysis of bovine plasma 3-hydroxybutyrate). Annales de Recherches Vétérinaires 17, 129-139.

Bergman EN (1990) Energy contributions of volatile fatty acids from the gastrointestinal tract in various species. Physiological Reviews 70, 567-590.

Binnerts WT, Van't Klooster ATh \& Frens AM (1968) Soluble chromium indicator measured by atomic absorption in digestion experiments. Veterinary Record 82, 470.

Bratton CA \& Marshall EK (1939) A new coupling component for sulfanil-amide determination. Journal of Biological Chemistry 128, 537-550.

Brighenti F (1997) Simple method for quantitative analysis of short chain fatty acids in serum by gas-liquid chromatography. In Plant Polysaccharides in Human Nutrition: Structure, Function, Digestive Fate and Metabolic Effects, pp. 114-119 [F Guillon, G Abraham, R Amado, H Andersson, HG Asp, KE Bach Knudsen, M Champ and J Robertson, editors]. Nantes: INRA.

Bueno L (1972) Le rumen isolé in situ: absorption des acides gras volatils (The isolated in situ rumen: absorption of volatile fatty acids). Revue de Médecine Vétérinaire 123, 943-953.

Casse EA, Rulquin H \& Huntington GB (1994) Effect of mesenteric vein infusion of propionate on splanchnic metabolism in primiparous Holstein cows. Journal of Dairy Science 77, 32963303.

Chilliard Y, Bocquier F \& Doreau M (1998) Digestive and metabolic adaptations of ruminants to undernutrition, and consequences on reproduction. Reproduction Nutrition Development 38, 131-152.

Demigné C, Yacoub C, Morand C \& Remesy C (1991) Interactions between propionate and amino acid metabolism in isolated sheep hepatocytes. British Journal of Nutrition 65, 301-317.

Dijkstra J, Boer H, Van Bruchem J, Bruining M \& Tamminga S (1993) Absorption of volatile fatty acids from the rumen of lactating dairy cows as influenced by volatile fatty acid concentration, $\mathrm{pH}$ and rumen liquid volume. British Journal of Nutrition 69, 385-396.

Eisemann JH \& Huntington GB (1994) Metabolite flux across 
portal-drained viscera, liver, and hindquarters of hyperinsulinemic, euglycemic beef steers. Journal of Animal Science 72, 2919-2929.

Goetsch AL (1998) Splanchnic tissue energy use in ruminants that consume forage-based diets ad libitum. Journal of Animal Science 76, 2737-2746.

Gross KL, Harmon DL \& Avery TB (1990a) Portal drained viscera flux of nutrients in lambs fed alfalfa or maintained by total intragastric infusion. Journal of Animal Science 68, 214221.

Gross KL, Harmon DL, Minton JE \& Avery TB (1990b) Effects of isoenergetic infusions of propionate and glucose on portal drained viscera nutrient flux and concentrations of hormones in lambs maintained by total intragastric infusion. Journal of Animal Science 68, 2566-2574.

Harmon DL \& Avery TB (1987) Effects of dietary monensin and sodium propionate on net nutrient flux in steers fed a highconcentrate diet. Journal of Animal Science 65, 1610-1616.

Hogan JP \& Weston RH (1967) The digestion of chopped and ground roughages by sheep. II. The digestion of nitrogen and some carbohydrate fractions in the stomach and intestines. Australian Journal of Agricultural Research 18, 803-819.

Huhtanen P \& Jaakkola S (1995) Intraruminal infusion technique for the estimation of ruminal VFA production. Annales de Zootechnie 44, Suppl., 168.

Huhtanen P, Miettinen H \& Ylinen M (1993) Effect of increasing ruminal butyrate on milk yield and blood constituents in dairy cows fed a grass silage-based diet. Journal of Dairy Science 76, $1114-1124$

Huntington GB (1990) Energy metabolism in the digestive tract and liver of cattle: influence of physiological state and nutrition. Reproduction Nutrition Development 30, 35-47.

Huntington GB \& Prior RL (1985) Net absorption of amino acids by portal-drained viscera and hind half of beef cattle fed a high concentrate diet. Journal of Animal Science 60, 1491-1499.

Huntington GB, Reynolds PJ \& Tyrrell HF (1983) Net absorption and ruminal concentrations of metabolites in nonpregnant dry Holstein cows before and after intraruminal acetic acid infusion. Journal of Dairy Science 66, 1901-1908.

Institut National de la Recherche Agronomique (1989) Ruminant Nutrition Recommended Allowances and Feed Tables $[\mathrm{R}$ Jarrige, editor]. Paris: INRA/John Libbey Eurotext.

Isserty A, Ortigues I \& Rémond D (1998) Mesure des débits splanchniques par dilution de marqueur: comparaison de quatre méthodes de dosage de l'acide para-amino-hippurique (Measurement of splanchnic blood flows by marker dilution: comparison of four analytical methods of para-amino-hippuric acid). Reproduction Nutrition Development 38, 93-106.

Jouany JP (1982) Volatile fatty acids and alcohol determination in digestive contents, silage juices, bacterial cultures and anaerobic fermentor contents. Sciences des Aliments 2, 131-144.

Katz ML \& Bergman EN (1969) Simultaneous measurements of hepatic and portal blood flow in the sheep and dog. American Journal of Physiology 216, 946-952.

Krehbiel CR, Harmon DL \& Schnieder JE (1992) Effect of increasing ruminal butyrate on portal and hepatic nutrient flux in steers. Journal of Animal Science 70, 904-914.

Kristensen NB, Danfaer A, Tetens V \& Agergaard N (1996) Portal recovery of intraruminally infused short-chain fatty acids in sheep. Acta Agriculturae Scandinavica Section A Animal Science 46, 26-38.

Kristensen NB, Pierzynowsky S \& Danfaer A (1999) Net portal appearance of volatile fatty acids in sheep intraruminally infused with mixtures of acetate, proprionate, isobutyrate, butyrate and valerate. Journal of Animal Science (In the Press).

Leng RA, Steel JW \& Luick JR (1967) Contribution of propionate to glucose synthesis in sheep. Biochemical Journal 103, 785-790.
Lindsay DR (1993) Metabolism of the portal drained viscera. In Quantitative Aspects of Ruminant Digestion and Metabolism, pp. 267-289 [JM Forbes and J France, editors]. Wallingford: CAB International.

Lomax MA \& Baird GD (1983) Blood flow and nutrient exchange across the liver and gut of the dairy cow. Effects of lactation and fasting. British Journal of Nutrition 49, 481-496.

Marsh WH, Fingerhut B \& Miller H (1965) Automated and manual direct methods for the determination of blood urea. Clinical Chemistry 11, 624-627.

Miettinen H \& Huhtanen P (1996) Effects of the ratio of ruminal propionate to butyrate on milk yield and blood metabolites in dairy cows. Journal of Dairy Science 79, 851-861.

Mould FL \& Ørskov ER (1983/84) Manipulation of rumen fluid pH and its influence on cellulolysis in sacco, dry matter degradation rumen microflora of sheep offered either hay or concentrate. Animal Feed Science and Technology 10, 1-14.

Nozière P, Attaix D, Bocquier F \& Doreau M (1999a) Effects of underfeeding and refeeding on weight and metabolism of splanchnic organs in ewes. Journal of Animal Science 77, 2279-2290.

Nozière P, Rémond D, Bernard L \& Doreau M (1999b) Effect of underfeeding on portal net fluxes of glucose, lactate, ammonia, urea and amino acids in ewes. South African Journal of Animal Science 29, 236-237.

Nozière P, Rémond D, Ferlay A \& Doreau M (1998) Differences between blood and plasma concentrations of acetate, $\beta$-hydroxybutyrate, glucose, ammonia and urea: implications for measurement of portal net fluxes in ewes. Reproduction Nutrition Development 38, 509-518.

Ortigues I \& Doreau M (1995) Responses of the splanchnic tissues of ruminants to changes in intake: absorption of digestion end products, tissue mass, metabolic activity and implications to whole animal energy metabolism. Annales de Zootechnie 44, 321-346.

Ortigues I, Durand D \& Lefaivre J (1994) Use of para-amino hippuric acid to measure blood flows through portal-drainedviscera, liver and hindquarters in sheep. Journal of Agricultural Science, Cambridge 122, 299-308.

Peters JP, Shen RYW, Robinson JA \& Chester ST (1990) Disappearance and passage of propionic acid from the rumen of the beef steer. Journal of Animal Science 68, 3337-3349.

Rémond D, Chaise JP, Delval E \& Poncet C (1993) Net flux of metabolites across the ruminal wall of sheep fed twice a day with orchardgrass hay. Journal of Animal Science 71, 25292538.

Rémond D, Ortigues I \& Jouany JP (1995) Energy substrates for the rumen epithelium. Proceedings of the Nutrition Society 54, 95-105.

Rémond D, Ortigues-Marty I, Isserty A \& Lefaivre J (1998) Technical note: Measuring portal blood flow in sheep using an ultrasonic transit time flow probe. Journal of Animal Science 76, 2712-2716.

Reynolds CK (1995) Quantitative aspects of liver metabolism in ruminants. In Ruminant Physiology: Digestion, Metabolism, Growth and Reproduction, pp. 351-371 [WV Engelhardt, S Leonhard-Marek, G Breves and D Giesecke, editors]. Stuttgart: Ferdinand Enke Verlag.

Reynolds CK \& Huntington GB (1988) Partition of portal-drained visceral net flux in beef steers. 2. Net flux of volatile fatty acids, D- $\beta$-hydroxybutyrate and L-lactate across stomach and poststomach tissues. British Journal of Nutrition 60, 553-562.

Sakata T \& Tamate H (1978) Rumen epithelial cell proliferation accelerated by rapid increase in intraruminal butyrate. Journal of Dairy Science 61, 1109-1113.

Seal CJ \& Parker DS (1994) Effect of intraruminal propionic acid infusion on metabolism of mesenteric- and portal-drained viscera 
in growing steers fed a forage diet: I. Volatile fatty acids, glucose, and lactate. Journal of Animal Science 72, 1325-1334.

Shriver BJ, Hoover WH, Sargent JP, Crawford RJ Jr \& Thayne WV (1986) Fermentation of a high concentrate diet as affected by ruminal $\mathrm{pH}$ and digesta flow. Journal of Dairy Science 69, 413-419.

Tabaru H, Ikeda K, Kadota E, Murakami Y, Yamada H, Sasaki N \& Takeuchi A (1990) Effects of osmolality on water, electrolytes and VFAs absorption from the isolated ruminoreticulum in the cow. Japanese Journal of Veterinary Science 52, 91-96.

Tetens V, Kristensen NB \& Calder AG (1995) Measurement of ${ }^{13} \mathrm{C}$ enrichment of plasma lactate by gas chromatography/isotope ratio mass spectrometry. Analytical Biochemistry 67, 858-862.

Weatherburn MW (1967) Phenol-hypochlorite reaction for determination of ammonia. Analytical Chemistry 39, 971-973.

Weekes TEC \& Webster AJF (1975) Metabolism of butyrate in the tissue of the sheep gut. British Journal of Nutrition 33, 425438.

Weller RA, Gray FV, Pilgrim AF \& Jones GB (1967) The rates of production of volatile fatty acids in the rumen. IV. Individual and total fatty acids. Australian Journal of Agricultural Research 18, $107-118$. 